\title{
Enhanced drug metabolism in young children with cystic fibrosis
}

\author{
A C Parker, P Pritchard, T Preston, R L Smyth, I Choonara
}

\begin{abstract}
The effect of cystic fibrosis on caffeine metabolism was studied in young children using the caffeine breath test. Eight children with cystic fibrosis aged 2-6 years and nine age matched controls were studied on a single occasion, and the cumulative percentage of labelled caffeine exhaled as carbon dioxide measured over two hours. This was significantly higher in the patients with cystic fibrosis than in controls, suggesting an increase in the CYP1A2 metabolic pathway in the former. The fact that these were young children with minimal lung and liver disease suggests that enhanced drug metabolism in children with cystic fibrosis is hereditary rather than secondary to lung and liver damage.

(Arch Dis Child 1997;77:239-241)
\end{abstract}

Keywords: caffeine metabolism; cystic fibrosis

Several studies have suggested that there is increased drug metabolism in patients with cystic fibrosis. Adult patients with cystic fibrosis have enhanced $\mathrm{N}$-demethylation and 8hydroxylation of theophylline. ${ }^{12}$ These pathways involve two different isozymes of cytochrome $P-450$. Many of the adolescents and adults studied have chronic lung and liver disease, both of which can affect drug metabolism. ${ }^{3}{ }^{4}$ We are aware of no studies in young children, probably because of limitations on the number and volume of blood samples that can be collected.

We, and others, have used the caffeine breath test to study both drug interactions and the effect of disease on drug metabolism..$^{5-7}$ The test involves the use of a non-radioactive stable isotope $\left({ }^{13} \mathrm{C}\right.$ on the 3-methyl group of caffeine). The caffeine is given orally and undergoes $3-\mathrm{N}$-demethylation, which is a cytochrome $P-450$ dependent reaction (CYP1A2). After $\mathrm{N}$-demethylation the labelled methyl group enters the one carbon pool as it is converted to formaldehyde, formate, and bicarbonate, and then exhaled as carbon dioxide. We studied the effect of cystic fibrosis on caffeine metabolism in children using the caffeine breath test.

\section{Methods}

PLAN OF STUDY

The study was approved by the local ethics committee. Informed consent was obtained from the children and their parents before beginning the study. We recruited eight children with cystic fibrosis aged 2-6 years and nine age matched controls, all patients at Alder Hey Children's Hospital, Liverpool. The clinical details of the two groups of patients are given in table 1 . The children with cystic fibrosis all had normal liver function tests and relatively normal respiratory function (forced expiratory volume in one second $\left(\mathrm{FEV}_{1}\right) /$ predicted $\mathrm{FEV}_{1}$ ) as shown in table 1 . The table shows the Northern chest $x$ ray score for the patients with cystic fibrosis. ${ }^{8}$ None of the children with cystic fibrosis had evidence of an acute infection, although three (patients 3, 6, and 8) were carriers of Pseudomonas aeruginosa. Six children with cystic fibrosis were homozygous for the common genotype $\delta \mathrm{F} 508$, one was homozygous for the G551D genotype, and the genotypes in the eighth were $\delta$ F $508 /$ G551D. All the children with cystic fibrosis were taking daily vitamins, pancreatic enzymes, vitamin $\mathrm{E}$, fluoride, and prophylactic antibiotics (flucloxacillin or cefaclor). All, except patients 2 and 6 , were also receiving inhaled steroids and bronchodilators. Drugs in the control group were as follows: $\mathrm{C} 1$, cisapride; $\mathrm{C} 2$, cisapride and co-amoxiclav; C3, nitrofurantoin; $\mathrm{C} 4$, gaviscon; $\mathrm{C} 5$, gaviscon, metronidazole, and amoxycillin; C6, cisapride. Patient C9 had not received any anticonvulsant medication before being studied. None of the children with gastro-oesophageal reflux or oesophagitis had evidence of Helicobacter pylori infection.

\section{CAFFEINE BREATH TEST PROCEDURE}

All subjects abstained from caffeinated products for 20 hours and fasted for at least four hours before the caffeine breath test. All breath tests started between 0900 and $1000 \mathrm{~h}$. The subjects remained seated for 10 minutes before collecting the first breath sample. They were kept occupied by the research nurse throughout the whole test in order to minimise physical activity which can affect carbon dioxide production and result in dilution of the labelled carbon dioxide. ${ }^{9}$ Labelled caffeine $(3 \mathrm{mg} / \mathrm{kg}$ ) was given dissolved in water and mixed with sugar free squash to disguise its bitter taste. The solution was taken by mouth, followed by a $20 \mathrm{ml}$ water rinse of the container.

Breath samples were collected by getting children to blow into a sample balloon (Alveosampler; Quintron). Samples were collected at $-20,-10,-1,15,30,45,60,75,90,105$, and 120 minutes after ingestion of caffeine. Expired air $(10 \mathrm{ml})$ was removed from the balloon and transferred by syringe into a headspace analyser vial (Chromacol) that had been preevacuated. Samples were unaffected by eight 
weeks of storage in these vessels. Samples were posted to the Scottish Universities Research and Reactor Centre for analysis.

ANALYTICAL METHODS

${ }^{13} \mathrm{C}$ enrichment of breath carbon dioxide was determined by continuous flow isotope ratio mass spectrometry. ${ }^{10}$ Breath samples $(10 \mathrm{ml})$ were injected automatically into the gas preparation device (Roboprep-G; Europa Scientific), where they were in turn, dried, resolved from interfering components by gas chromatography, and passed - using helium as carrier - into the electron impact ion source of an isotope ratio mass spectrometer (Tracermass; Europa Scientific). The ion beams $\mathrm{m} / \mathrm{z} 44, \mathrm{~m} / \mathrm{z} 45$, and $\mathrm{m} / \mathrm{z} 46$ were monitored continuously and used to calculate the partial pressure and ${ }^{13} \mathrm{C}$ enrichment of carbon dioxide, with reference to a $2 \%$ $\begin{array}{lll}\mathrm{CO}_{2} / 98 \% & \mathrm{~N}_{2} & \text { gas supply which had been }\end{array}$ calibrated against a bicarbonate standard of known ${ }^{13} \mathrm{C}$ enrichment. Duplicates of each breath sample were analysed.

CALCULATIONS AND STATISTICAL ANALYSIS

The ${ }^{13} \mathrm{C}$ enrichment of exhaled carbon dioxide was converted from delta units to atom $\%$ using the accepted atom fraction of the international bicarbonate standard. ${ }^{11}{ }^{13} \mathrm{C}$ enrichment was expressed as atom $\%{ }^{13} \mathrm{C}$ excess, by subtracting the average predose enrichment from each postdose measurement. Cumulative ${ }^{13} \mathrm{CO}_{2}$ output was calculated by averaging the measured ${ }^{13} \mathrm{C}$ enrichment of the eight breath samples taken during the first two hours following administration of the ${ }^{13} \mathrm{C}$-caffeine dose and multiplying this by the average output of $\mathrm{CO}_{2}$ over this period (assumed to be $24 \mathrm{mmol}$ $\mathrm{CO}_{2} / \mathrm{kg}$ body weight ${ }^{12}$ ). This was expressed as a percentage of the caffeine dose.

There was no significant change in $\mathrm{CO}_{2}$ partial pressure either in breath samples analysed during the breath test for each patient or in the group overall. The mean (SD) $\mathrm{CO}_{2}$ partial pressure was $3.06(0.52) \%$.

The reproducibility of the assay derived from the average of 40 replicated breath analyses was 0.00104 atom $\%{ }^{13} \mathrm{C}$ excess. This equates to $1.11 \%$ recovery of a typical caffeine dose.

Student's $t$ test was used to compare the two groups. A sample size of 10 patients has a power of $90 \%$, assuming a difference of 3 in the mean score (of the percentage dose recovered over two hours) to be significant at the $5 \%$ level.

\section{Results}

There was no significant difference between the ages of the test and control children. There was a statistically significant difference in the percentage of labelled caffeine exhaled as carbon dioxide in young children with cystic fibrosis compared to controls (Student's $t$ test, $\mathrm{p}<0.02$ ). The individual findings for each patient are shown in table 1 and are illustrated graphically in fig 1 . The percentage of labelled caffeine exhaled as carbon dioxide was significantly greater in the patients with cystic fibrosis. The cumulative carbon dioxide exhaled over a two hour period is dependent on the 3-N-demethylation of caffeine. The higher levels in the patients with cystic fibrosis suggest an increase in their CYP1A2 metabolic pathway.

\section{Discussion}

The enhanced metabolism of drugs in patients with cystic fibrosis is well recognised. However, there have been few studies of drug metabolism in young children with mild cystic fibrosis. Our results show that young children with minimal pathophysiological changes in liver and lung function have enhanced metabolism of the pathway involving CYP1A2 enzyme. Changes

Table 1 Clinical details of patients and cumulative $2 \mathrm{~h} \mathrm{CO}_{2}$ output

\begin{tabular}{|c|c|c|c|c|c|c|c|c|c|c|}
\hline Patient & $\begin{array}{l}\text { Age } \\
\text { (years) }\end{array}$ & Sex & $\begin{array}{l}\text { Height } \\
(\mathrm{cm})\end{array}$ & Centile & $\begin{array}{l}\text { Weight } \\
(\mathrm{kg})\end{array}$ & Centile & $\begin{array}{l}\text { FEV/predicted } \\
F E V_{1} \%\end{array}$ & $\begin{array}{l}\text { Northern chest } \\
x \text { ray score }\end{array}$ & Diagnosis & $\begin{array}{l}\% \text { Caffeine } \\
\text { dose } \\
\text { cumulative } 2 \mathrm{~h} \\
\mathrm{CO}_{2}\end{array}$ \\
\hline 1 & 3 & M & 100 & 75th & 16.0 & 50th & N/A & 0 & $\begin{array}{l}\text { Cystic } \\
\text { fibrosis }\end{array}$ & 8.59 \\
\hline 2 & 3 & $\mathrm{~F}$ & 93 & 10th & 12.2 & $3 \mathrm{rd}$ & N/A & 3 & $\begin{array}{l}\text { Cystic } \\
\text { fibrosis }\end{array}$ & 8.16 \\
\hline 3 & 4 & $M$ & 103 & 20th & 15.6 & 10th & $83 \%$ & 4 & $\begin{array}{l}\text { Cystic } \\
\text { fibrosis }\end{array}$ & 6.17 \\
\hline 4 & 4 & $M$ & 98 & 10th & 15.0 & 10th & $84 \%$ & 3 & $\begin{array}{l}\text { Cystic } \\
\text { fibrosis }\end{array}$ & 7.16 \\
\hline 5 & 4 & $M$ & 107 & 60 th & 19.0 & 75th & $90 \%$ & N/A & $\begin{array}{l}\text { Cystic } \\
\text { fibrosis }\end{array}$ & 6.53 \\
\hline 6 & 5 & $\mathrm{~F}$ & 106 & 20 th & 16.5 & 10th & $79 \%$ & 4 & $\begin{array}{l}\text { Cystic } \\
\text { fibrosis }\end{array}$ & 5.45 \\
\hline 7 & 5 & $\mathrm{~F}$ & 106 & 20 th & 17.3 & 25 th & $122 \%$ & 4 & $\begin{array}{l}\text { Cystic } \\
\text { fibrosis }\end{array}$ & 8.18 \\
\hline 8 & 5 & $\mathrm{~F}$ & 103 & $3 \mathrm{rd}$ & 21.0 & 75th & $103 \%$ & 2 & $\begin{array}{l}\text { Cystic } \\
\text { fibrosis }\end{array}$ & 11.64 \\
\hline Mean (SD) & & & & & & & & & & $7.73(1.92)$ \\
\hline $\mathrm{C} 1$ & 2 & M & 97 & 97th & 16.5 & 97th & - & \multicolumn{2}{|c|}{ Gastro-oesophageal reflux } & 6.67 \\
\hline $\mathrm{C} 2$ & 3 & $\mathrm{~F}$ & 100 & 75th & 14.4 & 25th & - & \multicolumn{2}{|c|}{ Gastro-oesophageal reflux } & 3.08 \\
\hline C3 & 3 & $M$ & 100 & 75 th & 17.0 & 75th & - & \multicolumn{2}{|c|}{$\begin{array}{l}\text { Asthma, urinary tract } \\
\text { infections }\end{array}$} & 1.49 \\
\hline $\mathrm{C} 4$ & 3 & M & 103 & 90th & 16.5 & 75th & - & \multicolumn{2}{|c|}{ Oesophagitis } & 3.81 \\
\hline C5 & 4 & M & 117 & 97th & 17.3 & 50th & - & \multicolumn{2}{|c|}{ Gastro-oesophageal reflux } & 9.08 \\
\hline C6 & 5 & $\mathrm{~F}$ & 117 & 90th & 22.0 & 80th & - & \multicolumn{2}{|c|}{ Oesophagitis } & 3.40 \\
\hline $\mathrm{C} 7$ & 6 & M & 124 & 90th & 24.6 & 60th & - & \multicolumn{2}{|c|}{ Oesophagitis } & 2.29 \\
\hline $\mathrm{C} 8$ & 6 & M & 120 & 75th & 27.0 & 90th & - & \multicolumn{2}{|c|}{ Gastro-oesophageal reflux } & 8.21 \\
\hline $\begin{array}{l}\text { C9 } \\
\text { Mean (SD) }\end{array}$ & 6 & M & 120 & 75th & 20.0 & 25 th & - & \multicolumn{2}{|c|}{ Epilepsy } & $\begin{array}{l}1.86 \\
4.43(2.83)\end{array}$ \\
\hline
\end{tabular}

$\mathrm{N} / \mathrm{A}=$ not available $\mathrm{FEV}_{1}=$ forced expiratory volume in one second. 


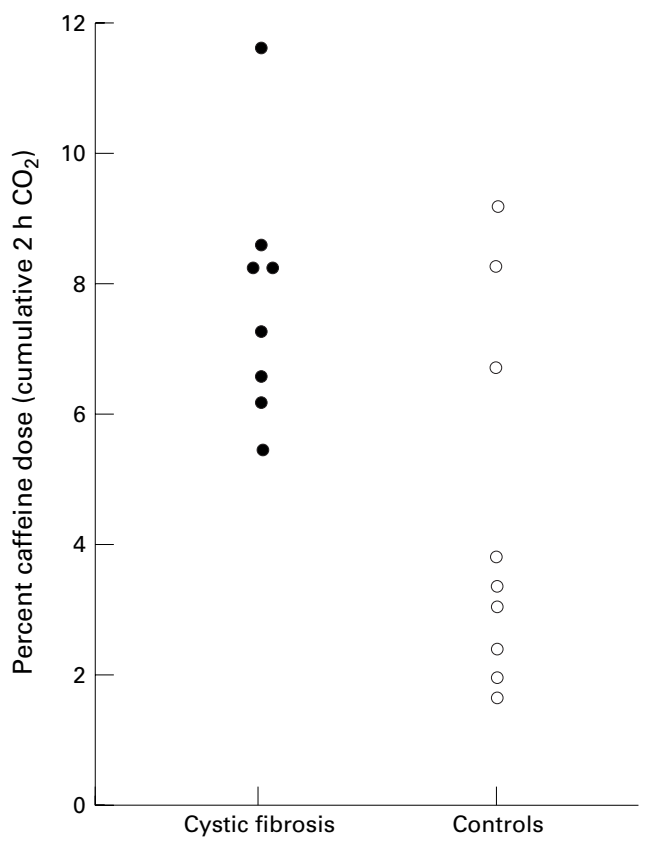

Figure 1 Individual data for per cent caffeine dose exhaled as labelled $\mathrm{CO}_{2}$ over two hours for patients with cystic fibrosis and controls.

in liver function or pulmonary disease can affect drug metabolism, ${ }^{13}{ }^{14}$ but these are more likely to result in impaired clearance, whereas patients with cystic fibrosis often have enhanced clearance of drugs. We have previously studied children with cystic fibrosis using the caffeine breath test ${ }^{7}$ and found it to be acceptable to both children and parents. Earlier studies have suggested that the total energy expenditure is increased in children with cystic fibrosis by up to $25 \% .{ }^{15}$ If this is the case, then the total $\mathrm{CO}_{2}$ exhaled will be increased. The labelled ${ }^{13} \mathrm{C}$ tracer would therefore be diluted and the percentage dose recovered would be underestimated. This would make our findings even more significant statistically.

Our results suggest that the increased activity of CYP1A2 enzyme in patients with cystic fibrosis is a genetic effect rather than secondary to pathophysiological changes in the lungs or liver. This is consistent with a recently published study showing enhanced drug clearance in patients with mild cystic fibrosis. ${ }^{16} \mathrm{~A}$ previous study failed to show an increase in CYP1A2 activity in activity in children with cystic fibrosis ${ }^{17}$ but this may have been related to the methods used. The study involved the collection of urine samples for only four hours after the administration of a dose of caffeine and the authors felt that this may have affected CYP1A2 ratios in some subjects. ${ }^{17}$

The advantage of using the caffeine breath test is that no blood or urine samples are needed. This makes it easier for the children involved in the study. Previous studies using the caffeine breath test have shown that a two hour cumulative exhalation of labelled carbon dioxide reflects $3-\mathrm{N}$-demethylation and that this is the appropriate measurement to use in comparing different studies. ${ }^{18}$ Further studies are required to determine whether other enzymes involved in the metabolism of drugs have an enhanced effect in either young children with cystic fibrosis or children with cystic fibrosis who have mild symptoms only.

We thank the Wellcome Trust (grant No 040145) for financial support. We thank Gill Croxton for her help in preparing the caffeine and Mrs Alexandra Longworth and Miss Ros Waring for typing the manuscript.

1 Isles A, Spino M, Tabachnik E, Levison H, Thiessen J, MacLeod S. Theophylline disposition in cystic fibrosis. Am Rev Respir Dis 1983;127:417-21.

2 Knoppert DC, Spino M, Beck R, Thiessen JJ, MacLeod SM. Cystic fibrosis: Enhanced theophylline metabolism may be linked to the disease. Clin Pharmacol Ther 1988;44: 254-64.

3 Kearns GL, Mallory GB, Crom WR, Evans WE. Enhanced hepatic drug clearance in patients with cystic fibrosis. $\mathcal{f}$ Pediatr 1990;117:972-9.

4 Kearns GL. Hepatic drug metabolism in cystic fibrosis: recent developments and future directions. Ann Pharmacother 1993;27:74-9.

5 Levitsky LL, Schoeller DA, Lambert GH, Edidin DV. Effect of growth hormone therapy in growth hormone-deficient demethylation of caffeine as m-450-dependent 3-N${ }^{13} \mathrm{CO}_{2}$ breath test. Dev Pharmacol Ther 1989;12:90-5.

6 Rost KL, Brosicke H, Brockmoller J, Scheffler M, Helge H, Roots I. Increase of cytochrome P450 1A2 activity by omeprazole: evidence by the ${ }^{13} \mathrm{C}-(\mathrm{N}-3$-methyl)-caffeine breath test in poor and extensive metabolizers of breath test in poor and extensive metabolizers

7 Parker AC, Preston T, Heaf D, Kitteringham NR, Choonara I. Inhibition of caffeine metabolism by ciprofloxacin in children with cystic fibrosis as measured by the caffeine breath test. Br f Clin Pharmacol 1994;38:573-6.

8 Conway SP, Pond MN, Bowler I, et al. The chest radiograph in cystic fibrosis: a new scoring system compared with the Chrispin-Norman and Brasfield scores. Thorax 1994;49: 860-2.

9 Schoeller DA, Schneider JF, Solomons NW, Watkins JB, Klein PD. Clinical diagnosis with the stable isotope ${ }^{13} \mathrm{C}$ in $\mathrm{CO}_{2}$ breath tests: methodology and fundamental considerations. F Lab Clin Med 1977;90:412-21.

10 Preston T, McMillan DC, Rapid sample throughput for biomedical stable isotope tracer studies. Biomed Environ Mass Spectrom 1988;16:229-35.

11 Craig H. The geochemistry of stable carbon isotopes. Geochim Cosmochim Acta 1957;3:53-92.

12 Lambert $\mathrm{GH}$, Kotake AN, Schoeller DA. The $\mathrm{CO}_{2}$ breath tests as monitors of cytochrome P-450 dependent mixed function mono-oxygenase system in metabolism. In: MacLeod SM, Okey D, Spielberg SP, eds. Developmental pharmacology. New York: Alan R Liss, 1983:119-45.

13 Mazoit J-X, Sandouk P, Zetlaoui P, Scherrman J-M. Pharmacokinetics of unchanged morphine in normal cirrhotic subjects. Anesth Analg 1987;66:293-8

14 Souich P, McLean AJ, Lalka D, Erill S, Gibaldi M. Pulmonary disease and drug kinetics. Clin Pharmacol 1978;3:25766.

15 Shepherd RW, Holt TL, Vasques-Velasquez L, Coward WA, Prentic A, Lucas A. Increased energy expenditure in young children with cystic fibrosis. Lancet 1988;i:1300-3.

16 Kearns GL, Crom WR, Karlson KH, Mallory GB, Evans WE. Hepatic drug clearance in patients with mild cystic WE. Hepatic drug clearance in patients with
fibrosis. Clin Pharmacol Ther 1996;59:529-40.

17 Hamelin BA, Xu K, Valle F, Manseau L, Richer M, LeBel M. Caffeine metabolism in cystic fibrosis: enhanced M. Caffeine metabolism in cystic fibrosis: enhanced
xanthine oxidase activity. Clin Pharmacol Ther 1994;56: 521-9.

18 Kotake AN, Schoeller DA, Lambert GH, Baker AL, Schaffer DD, Josephs $\mathrm{H}$. The caffeine $\mathrm{CO}_{2}$ breath test: dose response and route of $\mathrm{N}$-demethylation in smokers and non-smokers. Clin Pharmacol Ther 1982;32:261-9. 